\title{
Occurrence and redescription of Sipalolasma arthrapophysis (Gravely, 1915) (Araneae: Barychelidae: Barychelinae) from India
}

\author{
S.M. Maqsood Javed ${ }^{1,4}$, Robert J. Raven ${ }^{2}$, Farida Tampal ${ }^{1} \&$ K. Thulsi Rao ${ }^{3}$ \\ ${ }^{1}$ World Wide Fund for Nature-India (WWF) - APSO, 818, Castle Hills, Road No. 2, Near NMDC, Vijayanagar Colony, Hyderabad, \\ Andhra Pradesh 500057, India \\ ${ }^{2}$ Queensland Museum, Grey Street, PO Box 3300, South Brisbane, 4101, Queensland, Australia \\ ${ }^{3}$ Eco-Research and Monitoring Laboratories, Nagarjunasagar Srisailam Tiger Reserve, Sundipenta, Kurnool District, Andhra \\ Pradesh 518102, India \\ Email: ${ }^{4}$ javedwwf2007@gmail.com
}

Date of publication (online): 26 May 2010 Date of publication (print): 26 May 2010 ISSN 0974-7907 (online) | 0974-7893 (print)

Editor: Ansie Dippenaar

\section{Manuscript details:}

Ms \# 02387

Received 18 January 2010

Final revised received 05 April 2010

Finally accepted 06 April 2010

Citation: Javed, S.M.M., R.J. Raven, F. Tampal \& K.T. Rao (2010). Occurrence and redescription of Sipalolasma arthrapophysis (Gravely, 1915) (Araneae: Barychelidae: Barychelinae) from India. Journal of Threatened Taxa 2(5): $867-$ 875.

Copyright: (C) S.M. Maqsood Javed, Robert J. Raven, Farida Tampal \& K. Thulsi Rao 2010. Creative Commons Attribution 3.0 Unported License. JoTT allows unrestricted use of this article in any medium for non-profit purposes, reproduction and distribution by providing adequate credit to the authors and the source of publication.

\section{Author Details: See end of this article}

Author Contribution: SMMJ, FT and KTR conducted the field surveys; SMMJ and RJR identified the specimen; SMMJ, RJR, FT and KTR equally contributed in writing this article.

Acknowledgements: See end of this article
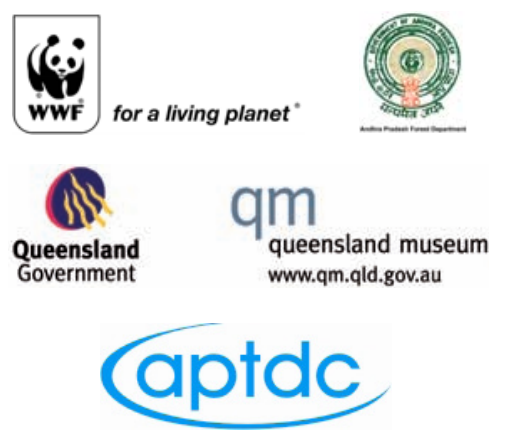

(c) (7) (ே)

OPEN ACCESS I FREE DOWNLOAD
Abstract: During a recent biodiversity survey a rare Brush-footed trapdoor spider, Sipalolasma arthrapophysis (Gravely, 1915) was recorded from the State of Andhra Pradesh, India for the first time and the second record from India. A detailed description with photographs and illustrations of the male is provided.

Keywords: Andhra Pradesh, Ananthagiri, Brush-footed trapdoor spider

\section{INTRODUCTION}

The Brush-footed trapdoor spider family Barychelidae is represented worldwide by 44 genera and about 303 species, of which Diplothele gravelyi Siliwal et al., 2009, D. tenebrosus Siliwal et al., 2009, D. walshi O. PickardCambridge, 1890, Sason andamanicum Simon, 1888, S. rameshwaram Siliwal \& Molur, 2009, S. robustum O. Pickard-Cambridge, 1883, Sasonichus sullivani Pocock, 1900 and Sipalolasma arthrapophysis (Gravely, 1915) are reported from India (Gravely 1935; Pocock 1900; Platnick 2009; Siliwal et al. 2009; Siliwal \& Molur 2009).

The genus Sipalolasma Simon, 1892 is found in Africa, Malaysia, India and Sri Lanka, and represented by nine species. The five species recorded from Asia are: S. aedificatrix Abraham, 1924, S. arthrapophysis (Gravely, 1915), S. ellioti Simon, 1892, S. greeni Pocock, 1900, and S. ophiriensis Abraham, 1924. Of these, only S. arthrapophysis occurs in India but little is known about it. During a biodiversity inventory survey conducted by the World Wide Fund for Nature-India (WWF-India), Andhra Pradesh State Office (APSO) in collaboration with Andhra Pradesh Tourism Development Corporation (APTDC), Hyderabad, we collected a male and identified it as $S$. arthrapophysis albeit with some variations. This is the second record of $S$. arthrapophysis from India and the first recorded from the State of Andhra Pradesh, India (Image 1). A detailed description is provided using the same characters as used by Raven (1994).

\section{MATERIAL \& METHODS}

The measurements taken follow Raven (2005). It is given in millimetres, 


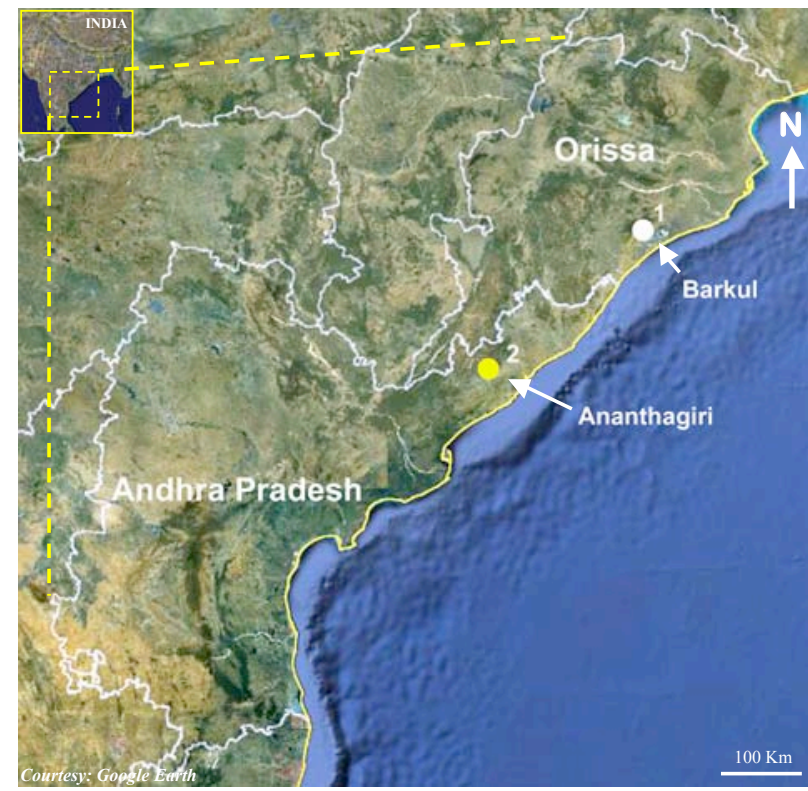

Image 1. Satellite image showing a map depicting records of S. arthrapophysis (Gravely, 1915) in two Indian states.

and was rounded off to one decimal where appropriate and were taken with a digital dial calipers with an error of $0.01 \mathrm{~mm}$. Photographs of the preserved specimen were taken with a Nikon Coolpix S550 mounted directly on the eye piece of a Lawrence \& Mayo stereomicroscope illuminated with a 100 watt light source; only minor colour corrections of the photos has been done. Illustrations were made with camera lucida attached to Olympus SZX 12 stereo zoom microscope. The specimen is deposited in the collections of the Zoological Survey of India, Freshwater Biology Regional Center, Arachnid section (ZSI/ FBRC/A), Hyderabad, Andhra Pradesh, India.

\section{TAXONOMY}

Barychelidae Simon, 1889

Barychelinae Simon, 1889

Sipalolasma Simon, 1892

Sipalolasma Simon, 1892: 123; Pocock 1900: 176;

Benoit 1966: 236; Raven 1985: 113; Platnick 1989: 94.

Cyclopelma Benoit, 1965: 302; Raven 1985: 151 (synonym).

Type species: Sipalolasma ellioti Simon, 1892.

\section{Diagnosis}

ALE not close to clypeal edge; ocular area as wide as long or slightly wider behind; fovea a deep circular pit or transverse or pro-curved or slightly re-curved; four spinnerets; tibial spur present in male; labium and maxilla with cuspules; claw tufts absent from female palp; body size 15-29 mm (Raven 1985; Dippenaar-Schoeman 2002).

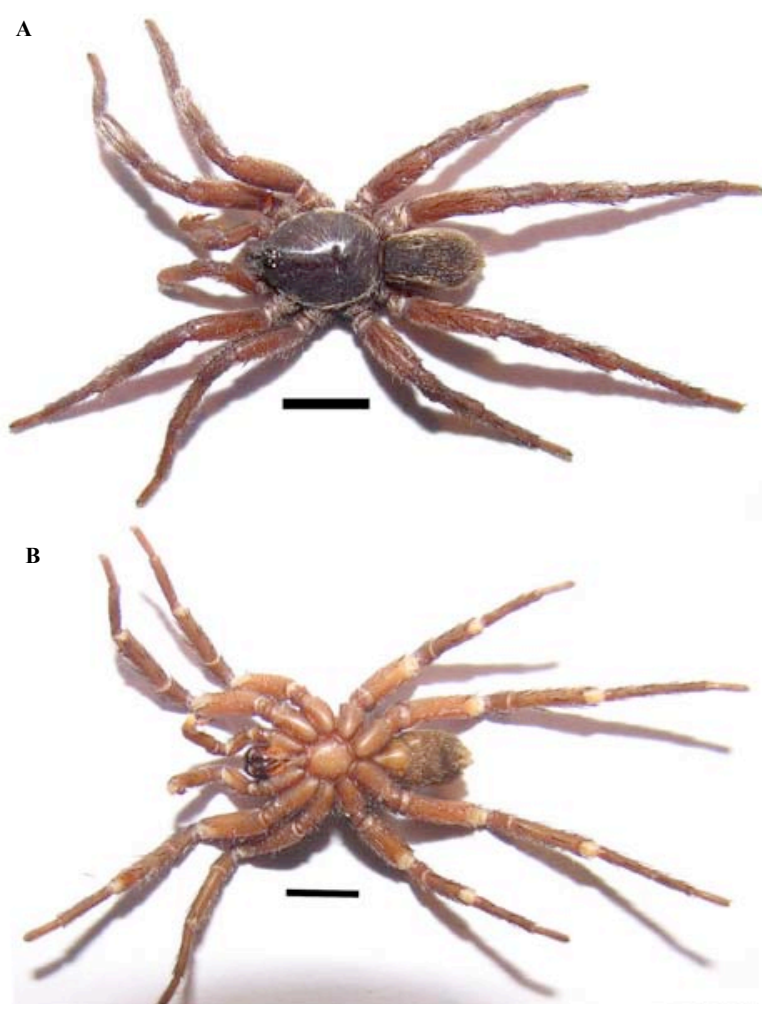

Image 2. Sipalolasma arthrapophysis male (ZSI/

FBRC/A-25). A - Dorsal view; B - Ventral view (scale 5mm)

\section{Distribution}

Africa (Afrotropical region, including from Mozambique, Ethiopia, South Africa and the Democratic Republic of Congo), Malaysia, India and Sri Lanka.

\section{Sipalolasma arthrapophysis (Gravely, 1915)}

(Figs. 1-2, Images 2-6)

Sasonichus arthrapophysis Gravely, 1915: 264, pl. 15, fig. 2; type specimen may be in ZSI, Kolkata not examined; Gravely 1921: 404, pl. 10, fig. 12.

Sipalolasma athrapophysis Raven, 1985: 116 (synonymy).

\section{Material examined}

1 male, 25.vii.2009, Ananthagiri, Vishakapatnam District, Andhra Pradesh, India, $18^{\circ} 15^{\prime} \mathrm{N} \& 8^{\circ} 59^{\prime} \mathrm{E}$, 1190m, coll. S.M. Maqsood Javed, ZSI/FBRC/A-25.

\section{Diagnosis (Male)}

ALE not close to clypeal edge; ocular area slightly wider behind; fovea transverse to slightly recurved; pair of enlarged tibial spur present in male; promarginal area of chelicera with 9-10 irregular sized teeth; cuspules on labium (ca. 4-5) and maxilla ca. 28-31; claw tufts present on all legs; body size 11-24 mm (Gravely 1915; Raven 1985). 

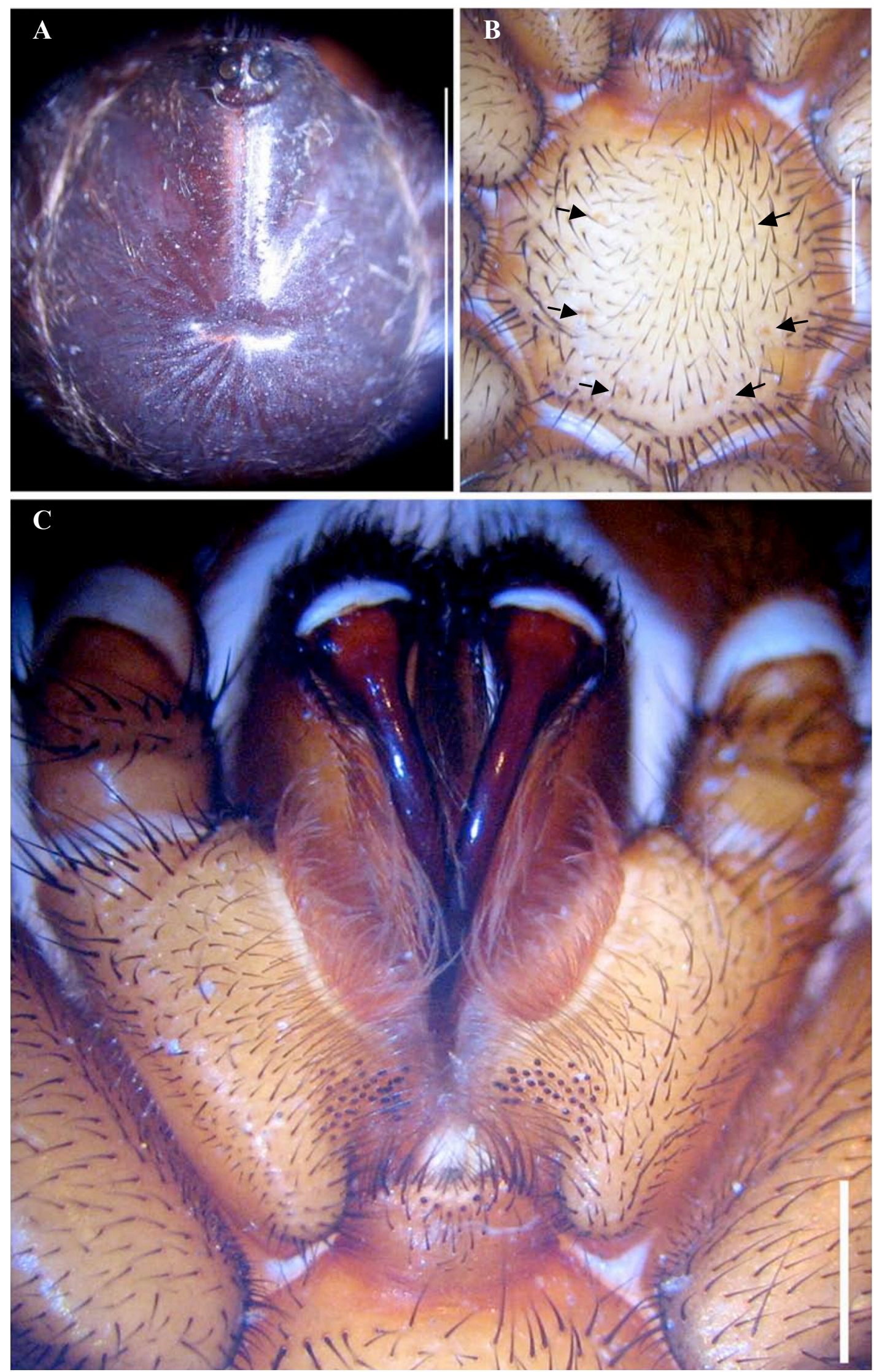

Image 3. S. arthrapophysis male (ZSI/FBRC/A-25). A - Carapace, dorsal view; B - Sternum, dorsal view (arrows pointing sigilla); $C$ - Maxillae and labium, dorsal view. (scale for $A, B=5 \mathrm{~mm} ; C=1 \mathrm{~mm}$ ) 

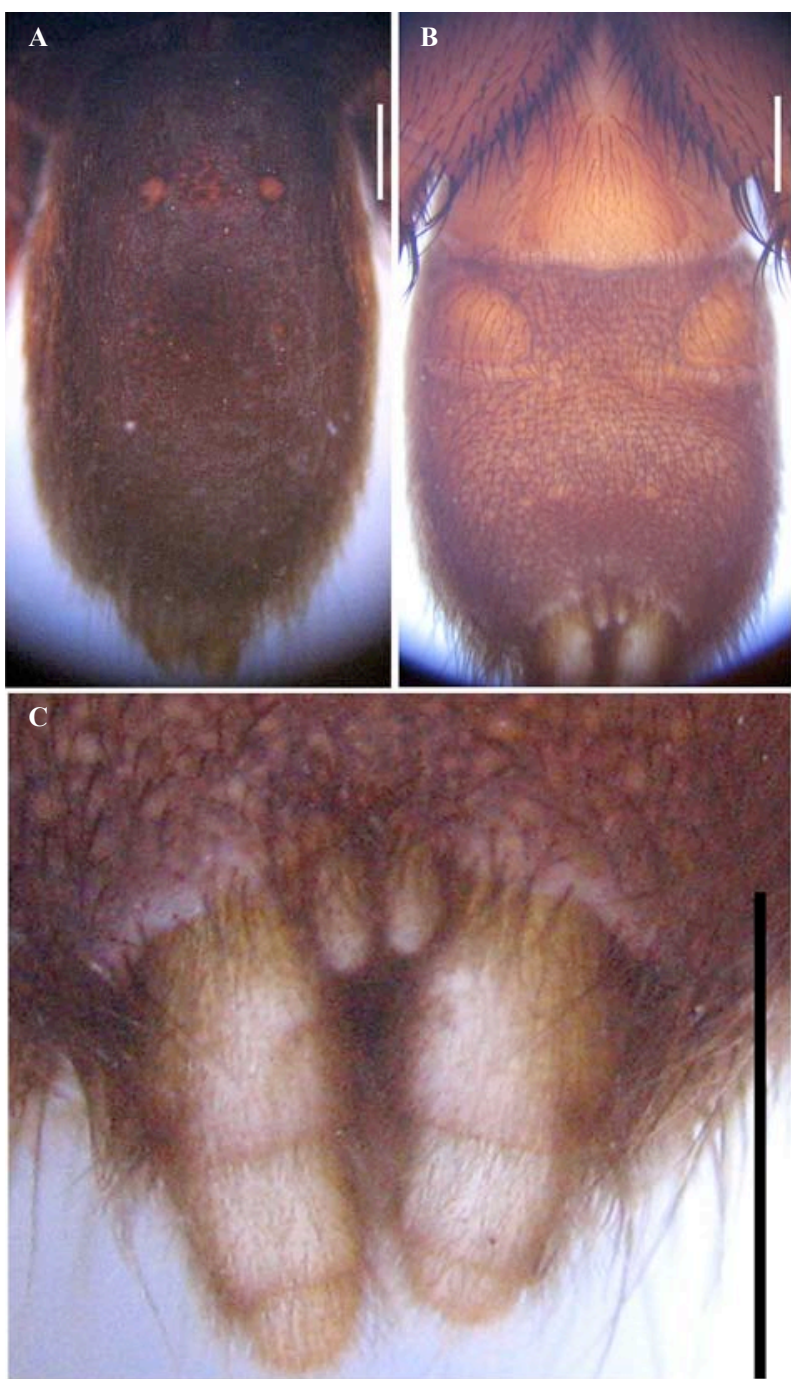

Image 4. S. arthrapophysis male (ZSI/FBRC/A-25). A- Abdomen, dorsal view; B- Abdomen, ventral view; C-Spinnerets, ventral view. (scale $1 \mathrm{~mm}$ )

\section{Description of male}

Carapace (excluding chelicerae) 6.13 long, 5.60 wide, chelicerae 3.20 long (after dissection 3.60). Abdomen 5.62 long, 3.39 wide. Spinnerets: PMS, 0.22 long, 0.6 wide, 0.4 apart; PLS, 0.42 basal, 0.30 middle, 0.20 distal (PLS $=0.92$ ); midwidth: $0.12,0.8,0.5$ respectively. Legs (including palpi) morphometry is given in Table 1.

Carapace (Images. 2A, 3A, 5B): length to width 1.09; ovate; uniform dark brown (brick red in life) with light brown hairs (golden in life) on margin, uniform cover of short dull brown hairs and short black setae or thorns scattered in between; clypeus 0.40 long, slanting downwards below ALE; fovea prominent, transverse and slightly re-curved; group of long and strong forward projecting black setae present between ALE; long black setae radiates from fovea to carapace edges (impression of tubercles distinct even after some setae were lost), the setae between ocular tubercle and fovea forms a prominent straight line.
Table 1. Morphometry of legs and palp of S. arthrapophysis, male, ZSI/FBRC/A-25 (measurements in $\mathrm{mm}$ )

\begin{tabular}{llllll}
\hline Leg parts & I & II & III & IV & Palp \\
\hline Femur & 4.80 & 4.54 & 4.12 & 5.70 & 2.60 \\
Patella & 3.20 & 2.56 & 2.23 & 2.58 & 1.62 \\
Tibia & 3.76 & 3.17 & 2.85 & 4.59 & 2.30 \\
Metatarsus & 4.14 & 3.55 & 4.22 & 6.58 & - \\
Tarsus & 1.85 & 1.82 & 1.75 & 1.79 & 1.02 \\
Patella + Tibia & 6.96 & 5.73 & 5.58 & 7.17 & - \\
Metatarsus + Tarsus & 5.99 & 5.57 & 6.45 & 8.37 & - \\
\hline Total & 17.75 & 15.64 & 15.17 & 21.24 & 7.54 \\
\hline Midwidth & & & & & \\
\hline Femur & 1.75 & 1.75 & 1.61 & 1.74 & 0.77 \\
Tibia & 1.21 & 1.20 & 1.18 & 1.18 & 1.04 \\
\hline
\end{tabular}
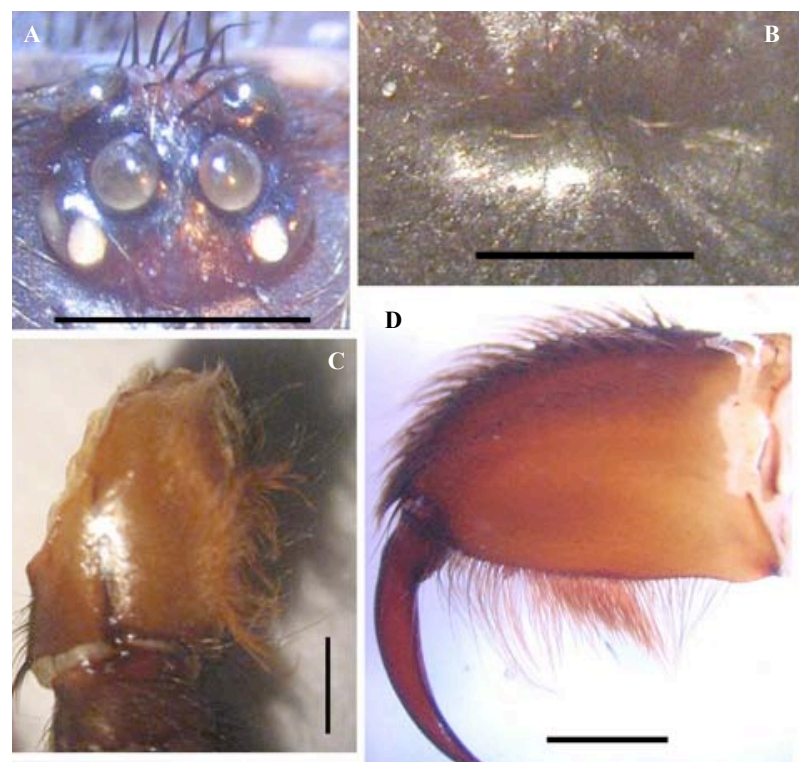

D

E
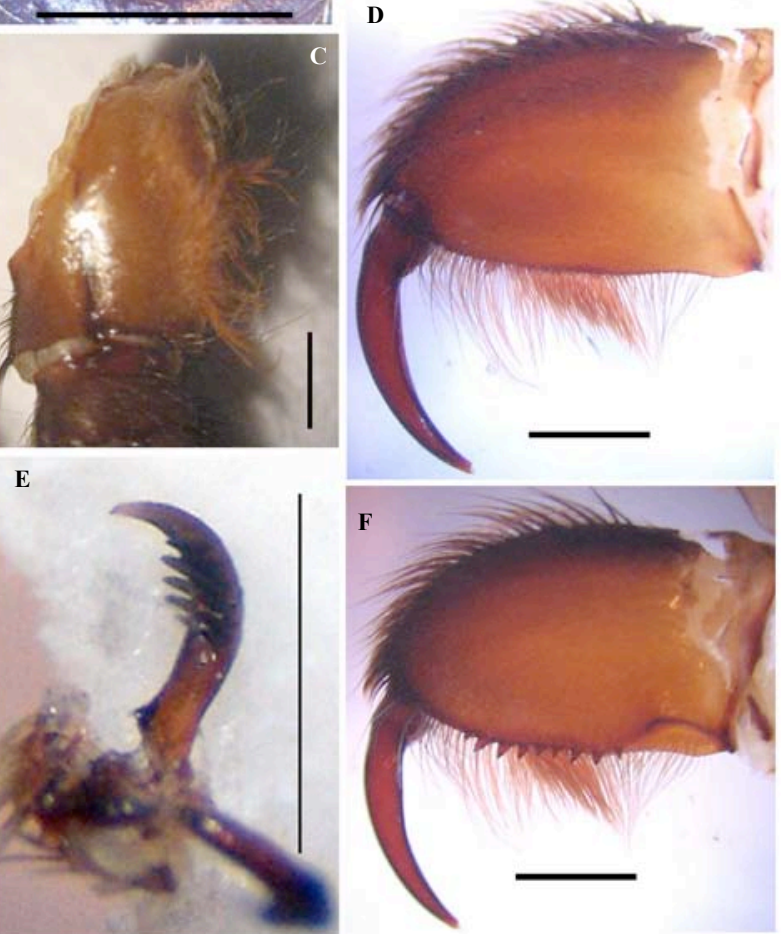

Image 5. S. arthrapophysis male (ZSI/FBRC/A-25).

A - Arrangement of eyes, ocular tubercle; B - Fovea;

C - Maxilla, prolateral view; D - Cheliceral, retrolateral face; E - Claw, showing small denticle (ca. 6) on one side;

F - Cheliceral, prolateral face. (scale for A-D \& F = 1mm; $\mathrm{E}=0.5 \mathrm{~mm}$ ). 

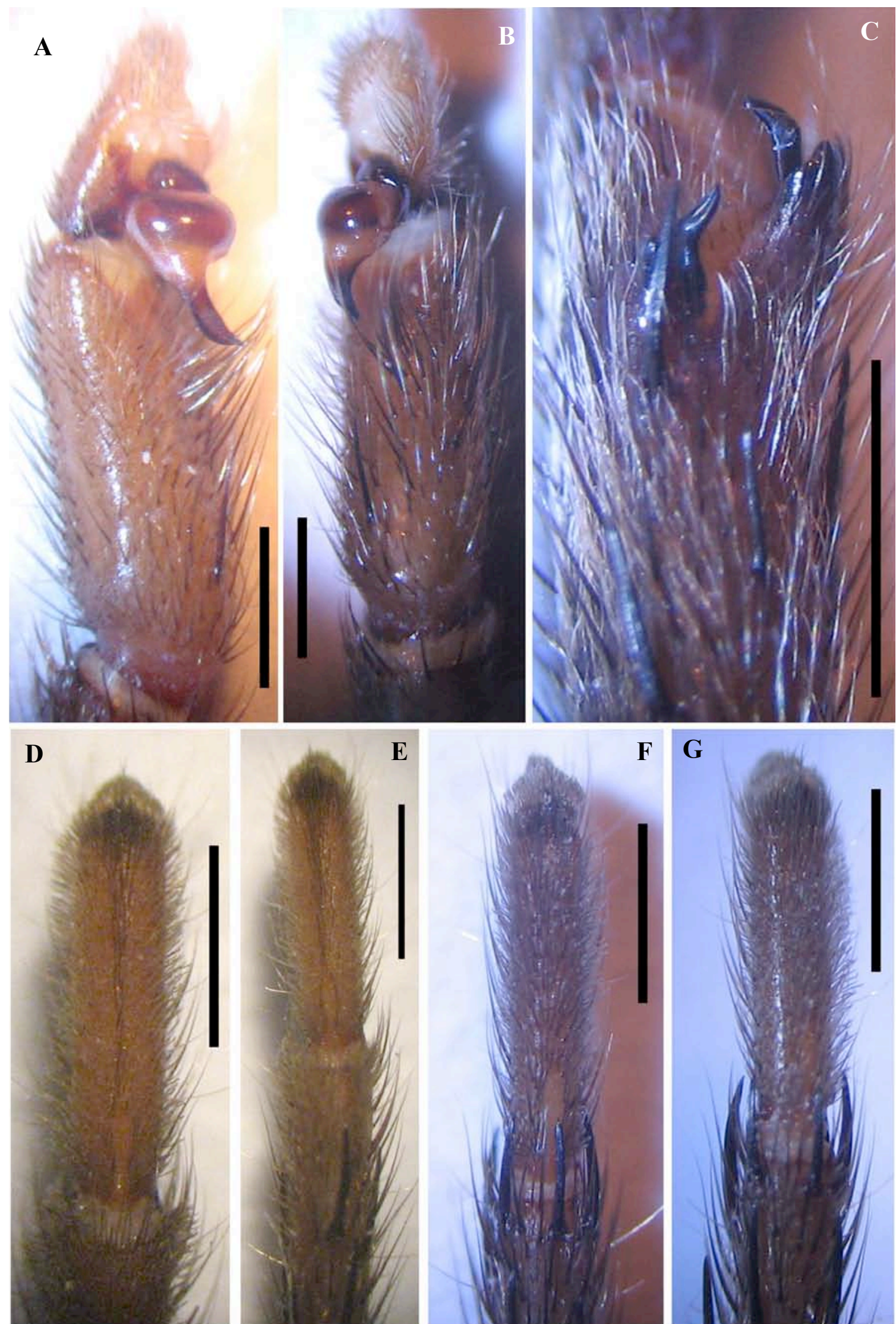

$\mathbf{E}$
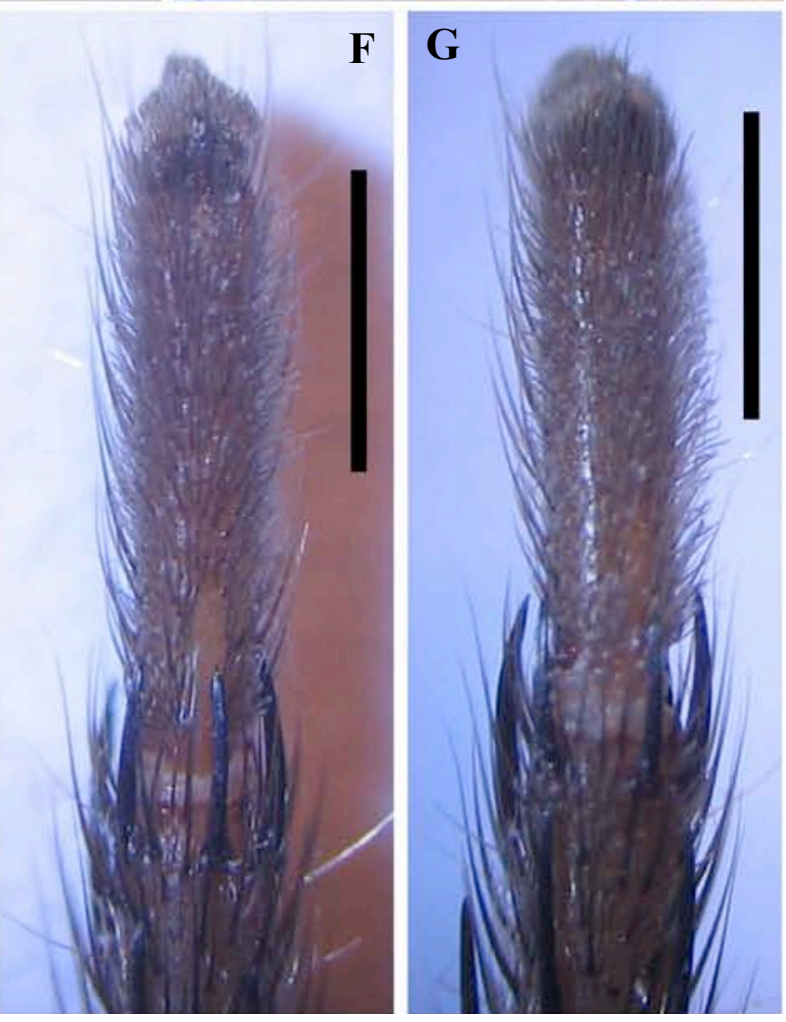

Image 6. S. arthrapophysis male (ZSI/FBRC/A-25). A - Palp, retrolateral view; B - Palp, prolateral view; C - Tibial spurs; D-G - Leg tarsus (I-IV), ventral view showing divided scopulae. (scale $1 \mathrm{~mm}$ ) 
Eyes (Image 5A, Fig. 1B): Eye tubercle distinct, as long as wide; ALE not close to clypeal edge; AME close to posterior eyes row; anterior eye row strongly procurved; posterior eye row slightly recurved. Eye group 1.20 long, 1.42 wide (ratio width to length 1.88). AME clearly larger than rest, ALE bigger than PLE and PME clearly smaller than others. Eye diameter: ALE, 0.20; AME, 0.24; PLE, 0.18; PME, 0.09. MOQ, 0.51 long, front width 0.70 , back width 0.79. Distance between ALE-ALE: 0.33, AME-AME: 0.14.

Maxillae (Images 3C, 5C, Figs. 1A \& D): Prolateral face smooth, glabrous, without lyra or setae; tuft of hair present on margin. Cuspules ca. 31/28 (left/right) in anterior corner, of these ca. 6 large at margin.

Labium (Images 3C, Figs. 1A \& E): About five cuspules in single procurved row on anterior part. Labiosternal groove broad with two separate large sigilla. Few small setae at center and very long in anterior half.

Chelicerae (Images 5D \& F, Figs. 2A \& B): Reddishbrown; lyra absent; spicules sparse and thin row on anterior prolateral region starts from base to base of fang; prolateral and retrolateral faces flat; promarginal area with 9 irregular sized teeth.

Sternum (Images 2B, 3B, Fig. 1E): 2.62 long, 2.80 wide. Almost circular, high in center, sloping gradually, covered with dense, black setae. Posterior angle sharp, but not extending between coxae IV. Setae marginal more dense and thorn-like. Pedicel pallid and not easily seen. Sigilla, three pairs, oval, very small and more centrally positioned, posterior largest, four lengths apart; middle pair not exactly half size of posterior, anterior exactly half size of posterior.

Palp (Images 6A \& B, Figs. 2D \& E): Short in comparison with legs. Cymbium straight, bi-lobed. Bulb round and enlarged, embolus with broad base and slightly twisted with pointed tip, flat and curved downwards (left bulb is with deformity). Four enlarged spines on prolateral tibia and one close to base on ventral side.

Legs (Images 5E, 6E-G, Figs. 1C, 2C): 4123. With rows of long and short hairs intermingled with strong setae and spines. Tarsi I-IV with scopulae entire divided by band of 2-4 setae, metatarsi I-IV with scopulae sparse on anterior region. Coxal bases as seen from above, (with I clearly widest, about 1.3 times length of II; IV as wide as I) Claw tufts on all legs. Tarsi I-IV with two claws, each claw with two rows (6 inner/4 outer) of small denticles. Pair of tibial spurs on leg I, base of distal spur with enlarged blunt tubercles, basal spur with long stout spine (left side tibia of leg I devoid of spurs and tubercle, may be absent through damage). Spines on all legs: I (Metatarsus ventral: $4 \mathrm{~m} \& \mathrm{p} \mathrm{2,r} 4$; Tibia dorsal/ventral: 2 m/p 2, r 3); Il (Metatarsus ventral: 4 m \& p 2, r 4; Tibia dorsal/ventral: 2 m/p 3, r 3); III (Metatarsus dorsal/ventral: 2 m/4 m \& p 3, r 3; tibia dorsal/ventral: 2 m/6 m [3 on distal end] \& p 2, r 2; patella dorsal: p 2, r 2 ; femur dorsal: $2 \mathrm{~m}$ \& $p 2, r 2$ ); IV (Metatarsus dorsal/ventral: $2 \mathrm{~m} / 6 \mathrm{~m}$ [2 on distal end] \& p 5, r 5; tibia dorsal/ventral: 2 m/6 m [3 on distal end] \& p 5, r 4; patella dorsal: p 2, r 2; femur dorsal: $2 m \& p 2, r 2)$. Elsewhere absent. Patellae of legs I-IV with knob at base and straight suture up to distal end on retro-lateral face.

Abdomen (Images 4A \& B): Longer than wide, dark brown, dorsally covered with thick mat of dark brown hair with large golden hairs (but, after a few days of preservation hair lost and exposed cuticle dorsally), ventrally thick mat of uniform brown hairs and anterior portion above epigastric furrow almost bare with very few light brown hairs; pair of sigilla on anterior dorsal side.

Spinnerets (Image 4C, Fig. 1E): Two pairs with thick dull brown hair. Apical end of PLS, dome-shaped.

\section{Variation}

The new material of Sipalolasma arthrapophysis from Andhra Pradesh differs from that illustrated by Gravely (1915) in morphometry; number of spines on the promarginal area of chelicera and cuspules on labium; embolus of bulb not much twisted; spines near the tibial spurs are little enlarged.

\section{Distribution}

Barkul in southeastern Orissa; Ananthagiri Hills $\left(18^{0} 15^{\prime} \mathrm{N}, 82^{0} 59^{\prime} \mathrm{E}\right)$, northeastern Andhra Pradesh, India.

\section{Natural history}

A male was found under a medium-size (about $1 \mathrm{~m}$ diameter) boulder on a mountain slope from a well camouflaged U-shaped burrow with two openings (burrow unfortunately destroyed while flipping the boulder). Gravely (1921) described a burrow constructed among stones and more or less loose soil and rubbish among the roots of Ficus bengalensis and Ficus religiosa, etc. It consists of a short and almost straight tube, somewhat wider in the middle and closed at each end by a trapdoor which is always hinged on the lower side, so that it hangs open when not held in place by the spider. Empty burrows are thus somewhat conspicuous objects, the whitish lining of the trap-door contrasting with the mouth of the dark burrow above it. The trapdoor of a full grown spider is about $10 \mathrm{~mm}$ in diameter. Males were found only up to August (Gravely 1921).

\section{DISCUSSION}

Gravely (1915) described S. arthrapophysis based on a single male specimen, and in 1921, he described a female with notes on their natural history. Here information on a second male specimen based on a record from Andhra Pradesh, India is provided. This species seems to be endemic to eastern parts of India. However we recorded several variations between the two specimens, when compared with the description provided by Gravely 


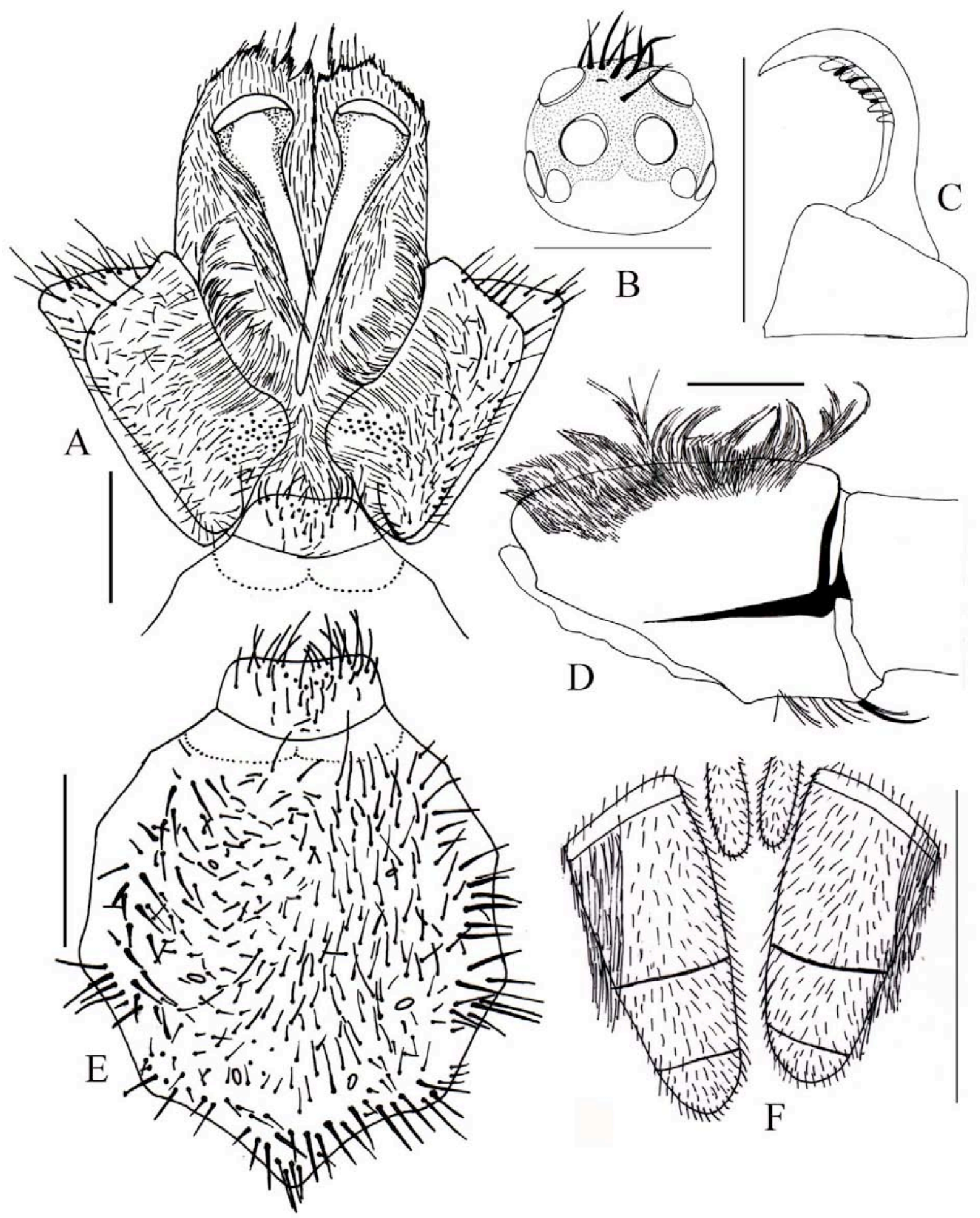

Figure 1. S. arthrapophysis male. A - Maxillae and labium, dorsal view; B - Arrangement of eyes, ocular tubercle; C - Claw, inner view showing small denticles (ca. 6/4) on inner/outer side; D - Maxilla, prolateral view; E - Sternum, dorsal view; F Spinnerets, ventral view, . (scale for C $=0.5 \mathrm{~mm}$; A, B \& D-F $=1 \mathrm{~mm}$ ) 

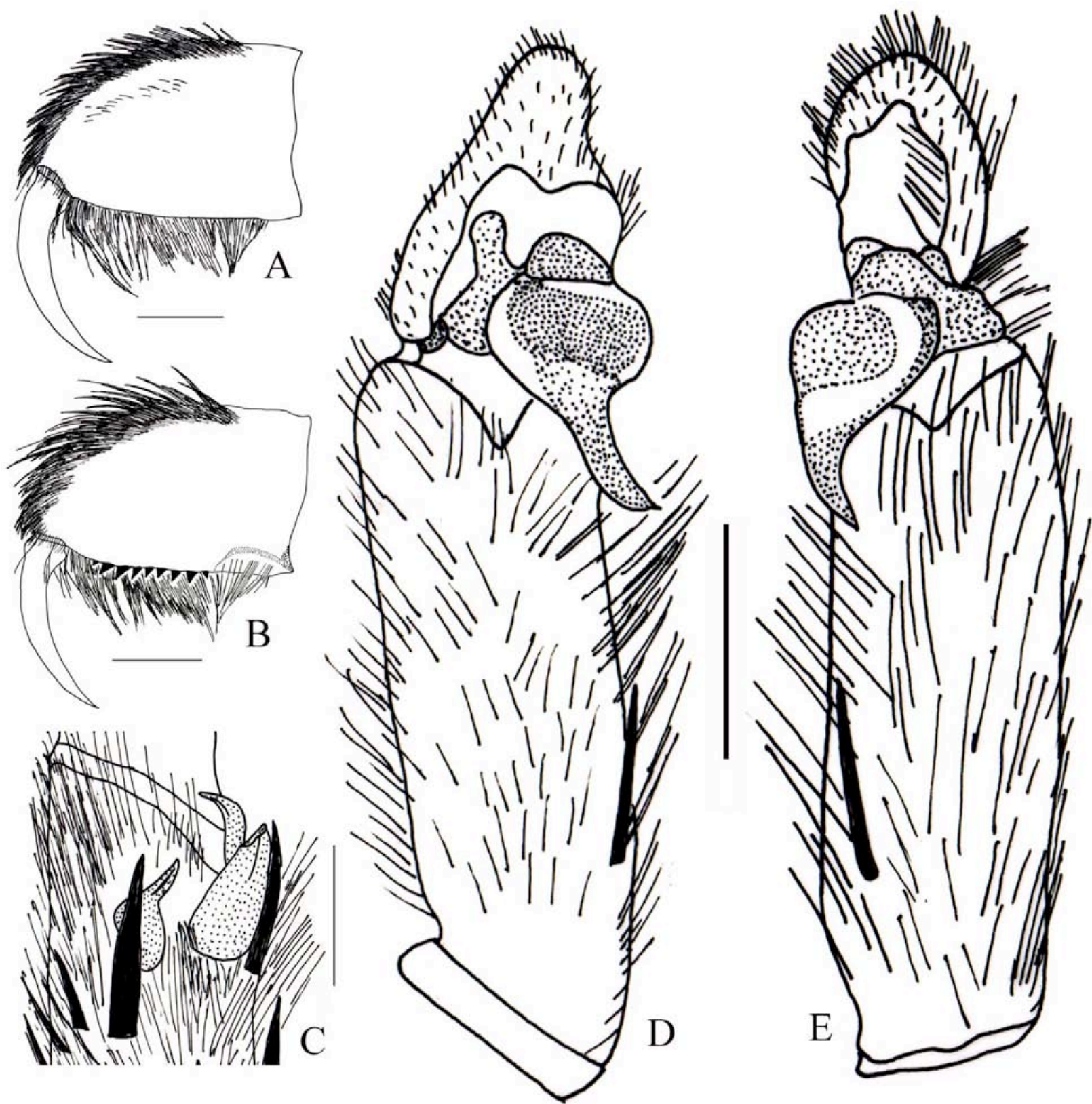

Figure 2. S. arthrapophysis male. A. Celicerae, retrolateral face. B. Celicerae, prolateral face. C. Tibial spurs. D. Palp, retrolateral view. E. Palp, prolateral view. (scale for C $=0.5 \mathrm{~mm} ; A, B, D, E=1 \mathrm{~mm}$ )

(1915), and as more specimens become available the level of variation will reveal whether they are one or two species. Presently the specimens recorded were from different heights above sea level and $135 \mathrm{~km}$ apart with difference in habitat selection.

\section{REFERENCES}

Abraham, H.C. (1924). Some mygalomorph spiders from the Malay Peninsula. Proceedings of the Zoological Society of London, 1091-1124pp.

Benoit, P.L.G. (1965). Etudes sur les Barychelidae du Centre Africain. II. Leptopelmatinae nouveaux. Revue de zoologie et de botanique africaines 71: 291-303.
Benoit, P.L.G. (1966). Les Barychelidae - Barychelinae africains et malgaches (Aran. - Orthogn.). Revue de zoologie et de botanique africaines 74: 209-241.

Dippenaar-Schoeman, A.S. (2002). Baboon and Trapdoor Spiders of Southern Africa: An Identification Manual. Plant Protection Research Institute Handbook no. 13, Agricultural Research Council, Pretoria, 128pp.

Gravely, F.H. (1915). Notes on Indian Mygalomorph Spiders. Records of the Indian Museum 11: 257-287.

Gravely, F.H. (1921). The Spiders and Scorpions of Barkuda Island. Records of the Indian Museum 22: 399-421.

Gravely, F.H. (1935). Notes on Indian mygalomorph spiders. II. Records of the Indian Museum 37: 69-84.

Platnick, N.I. (2009). The World Spider Catalog, Version 9.5, American Museum of Natural History. Website: < http://research.amnh.org/entomology/spiders/catalog/ 
BARYCHELIDAE. html> (Accessed on $12^{\text {th }}$ January 2010).

Platnick, N.I. (1989). Advances in Spider Taxonomy 1981-1987: A Supplement to Brignoli's Catalogue of the Araneae described between 1940 and 1981. Manchester University Press, Manchester, 673pp.

Pocock, R.I. (1900). The Fauna of British India, Including Ceylon and Burma. Arachnida Taylor and Francis, London, 279pp.

Raven, R.J. (1985). The spider Infraorder Mygalomorphae (Araneae): cladistics and systematics. Bulletin of the American Museum of Natural History 182: 1-180.

Raven, R.J. (1994). Mygalomorph spiders of the Barychelidae in Australia and the western Pacific. Memoirs of the Queensland Museum 35: 291-706.

Raven, R.J. (2005). A new tarantula species from northern Australia (Araneae, Theraphosidae). Zootaxa 1004: 15-28.

Siliwal, M. \& S. Molur (2009). Anew species of the genus Sason (Araneae: Barychelidae) from Rameshwaram Island, Tamil Nadu, India. Zootaxa 2283: 60-68.

Siliwal, M., S. Molur \& R. Raven (2009). Two new species of the genus Diplothele (Araneae, Barychelidae) from Orissa, India with notes on $D$. walshi. The Journal of Arachnology 37: 178-187.

Simon, E. (1892). Histoire naturelle des araignées. Librairie Encyclopédique de Roret, Paris 1: 1-256pp.
Author Details: Mr. S.M. MAQSOOD JAVED is a Senior Field Researcher-cum-Education Officer, World Wide Fund for Nature-India, Andhra Pradesh State Office, Hyderabad. His interest lies in biodiversity studies with special emphasis on arachnofauna and herpetofauna. DR. Robert J. RAVEN is a Senior Curator (Arachnida) \& Head, Terrestrial Biodiversity, Queensland Museum, Australia. He is working on Australian tarantulas and racing stripe spiders (family Miturgidae) and is the world authority on tarantula and trapdoor spiders. $\mathrm{He}$ has described new species world-wide, including 300+ new Australian species.

Ms. FARIDA TAMPAL is State Director of the Andhra Pradesh State Office of World Wide Fund for Nature - India, Hyderabad. She is interested in understanding the biodiversity of the Eastern Ghats with special emphasis on arachnofauna and herpetofauna.

Mr. K. ThulsI RAO is Assistant Conservator of Forests, Nagarjunasagar-Srisailam Tiger Reserve. He is the head of the Ecological Research and Monitoring Laboratories (ERM Labs), Sundipenta, Kurnool District, Andhra Pradesh. $\mathrm{He}$ is having immense experience and knowledge on biodiversity of different landscapes with special reference to the Eastern Ghats of India.

Acknowledgements: The authors are very thankful to Shri Hitesh Malhotra, IFS, Principal Chief Conservator of Forest (Wildlife) and Chief Wildlife Warden, Andhra Pradesh, Shri Sunil Kumar, IFS, Addl. Prl. Chief Conservator of Forest (Wildlife), Shri. R. Hampaiah, Chairman and Shri V.B. Ramana Murthy, Member Secretary, Andhra Pradesh Biodiversity Board for their constant support and encouragement. SMMJ and FT expresses gratitude to Shri Anil Kumar V. Epur, Chairman, WWF-AP State Committee, Hyderabad and Shri Ravi Singh, Secretary General \& CEO, WWF-India, New Delhi for constant support and encouragement. We express our thanks to Shri Swaranjit Sen, IPS (Retd.), Chairman, Shri B. Venkatesham, IAS, Managing Director and Shri P.V. Ramana Reddy, IFS, Executive Director, Andhra Pradesh Tourism Development Corporation, Hyderabad for constant support and permitting us to conduct biodiversity studies in APTDC Eco-tourism sites. RJR is grateful to Dr. Christine Rollard, Musee National d'Histoire Naturelle, Paris and Mrs. Janet Becaloni, Natural History Museum, London for their cooperation while visiting their respective collections. KTR expresses gratitude to Shri A.K. Nayak, IFS, Conservator of Forests \& Field Director, Nagarjunasagar Srisailam Tiger Reserve for constant encouragement and sustained support. We thank Dr. S.Z. Siddiqui, $O C$ and Shri. Anand Kumar Ayyaswamy, Sr. Zoological Assistant, FBRC, Hyderabad, Andhra Pradesh for laboratory support and literature. We thank Mr. Zeeshan A. Mirza for sharing literature. Lastly, we would like to thank Mr. P.S.M. Srinivas, Manager Corporate for exploring new places and all the WWF-Staff of APSO, Hyderabad for their constant support and timely suggestions. 